\title{
Fatty acid chemistry of Atrichum undulatum and Hypnum andoi
}

\author{
Boris Pejin ${ }^{1}$, Ljubodrag Vujisić ${ }^{1}$, Marko Sabovljević ${ }^{2}$, Vele Tešević ${ }^{1}$, Vlatka Vajs ${ }^{3}$ \\ ${ }^{1}$ University of Belgrade, Faculty of Chemistry, Department of Organic Chemistry, Belgrade, Serbia \\ ${ }^{2}$ University of Belgrade, Institute of Botany and Garden, Faculty of Biology, Belgrade, Serbia \\ ${ }^{3}$ University of Belgrade, Institute of Chemistry, Technology and Metallurgy, Center of Chemistry, Belgrade, Serbia
}

\begin{abstract}
The fatty acid compositions of the moss species Atrichum undulatum (Hedw.) P. Beauv. (Polytrichaceae) and Hypnum andoi A.J.E. Sm. (Hypnaceae) collected in winter time were analysed by gas chromatography (GC) and gas chromatography-mass spectrometry (GC-MS) as a contribution to their chemistry. Eight fatty acids were identified in the chloroform/methanol extract 1:1 of $A$. undulatum (linoleic acid, $26.80 \%$, palmitic acid, $22.17 \%$, $\alpha$-linolenic acid, $20.50 \%$, oleic acid, $18.49 \%$, arachidonic acid, $6.21 \%$, stearic acid, $3.34 \%$, cis-5,8,11,14,17-eicosapentaenoic acid, $1.52 \%$ and behenic acid, $1.01 \%)$, while six fatty acids were found in the same type of extract of $H$. andoi (palmitic acid, $63.48 \%$, erucic acid, $12.38 \%$, stearic acid, $8.08 \%$, behenic acid, $6.26 \%$, lignoceric acid, $5.16 \%$ and arachidic acid, 4.64\%). According to this study, the moss $A$. undulatum can be considered as a good source of both essential fatty acids for humans (linoleic acid and $\alpha$-linolenic acid) during the winter.
\end{abstract}

Keywords: Bryophytes, Mosses, phytochemistry, GC FID, GC-MS, linoleic acid; $\alpha$-linolenic acid.

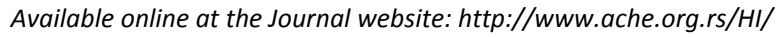

\section{RESEARCH NOTE}

UDC 582.32:547.395.4

Hem. Ind. 66 (2) 207-209 (2012)

doi: 10.2298/HEMIND110918074P
Bryophytes are the second largest group of land plants, after the flowering plants, with about 15,000 to 25,000 species and many intraspecific taxa [1]. They have settled all known ecosystems from desert to arctic with the exception of seas. In general, bryophytes consist of three very diverse groups: hornworts, liverworts, and mosses. The phytochemistry of bryophytes has been neglected for a long time because they are very small and difficult to collect in large amounts as pure samples [2]. Today these plants are known to be a reservoir of interesting and useful chemicals such as lipophilic terpenoids [3,4], acetogenins [5] and bisbibenzyl compounds [6]. Indeed, many new compounds are described from bryophytes, mainly liverworts, which possess oil-bodies rich in terpens and terpene like substances. Mosses, another group of bryophytes, remain less chemically studied since its members do not possess oil-bodies in their cells [7]. Fatty acids are known to be present within moss species but there are many assumptions and generalisations from small number of species studied [8-10]. Our continuing investigation of these compounds from mosses [11-15] has recently led to the identification of acetylenic fatty acids [16].

The objective of this study was to identify fatty acids of the moss species Atrichum undulatum (Hedw.) P. Beauv. (Polytrichaceae) and Hypnum andoi A.J.E. Sm.

Correspondence: B. Pejin, Department of Organic Chemistry, Faculty of Chemistry, University of Belgrade, Studentski trg 16, 11000 Belgrade, Serbia.

E-mail: brspjn@gmail.com

Paper received: 18 September, 2011

Paper accepted: 30 September, 2011
(Hypnaceae) by gas chromatography (GC) and gas chromatography/mass spectrometry (GC-MS) in corresponding chloroform/methanol extracts $1: 1$ as a contribution to their chemistry. To the best of our knowledge, there is no previous report on fatty acid chemistry of $H$. andoi, while only one report is available to date in the case of $A$. undulatum collected in sun-exposed habitat during summer time [9].

\section{EXPERIMENTAL}

Both mosses were collected in Germany in December 2007: $A$. undulatum in Königsforst near Köln and $H$. andoi in surrounding of Bonn. Voucher specimens were deposited in the Herbarium of the Institute of Botany, University of Belgrade, Serbia (bryophyte collection BEOU No. 4707 and 4709, respectively).

The moss samples were carefully selected and cleaned from soil and other contaminants. The gametophyte tips were used for the extraction. Air-dried parts of $A$. undulatum and $H$. andoi species were ground $(1 \mathrm{~g})$ and extracted three times with the system chloroform/methanol $1: 1$ for $1 \mathrm{~h}$ at room temperature (9.76 and $7.07 \%$ extract yield, respectively). The extracts were evaporated to dryness and further transesterified with $5 \%$ sulphuric acid in methanol $(v / v)$ for 4 $\mathrm{h}$ at $80^{\circ} \mathrm{C}$. The resulting methyl esters of fatty acids were analysed by comparing their GC FID chromatograms with the chromatogram of a standard mixture (Supelco 37) obtained under the same conditions, and/ /or by analysis of GC-MS data using NIST 5 and Wiley 7 
libraries. Three analysis replicates and three biological replicates were done.

The GC analyses were performed on an Agilent 7890A GC system equipped with a 5975C MSD and an FID detector, using a DB-23 column (30 $\mathrm{m} \times 0.25 \mathrm{~mm} \times$ $\times 0.25 \mu \mathrm{m})$. The injection volume was $1 \mu \mathrm{L}$ and injector temperature was $220^{\circ} \mathrm{C}$ with $10: 1$ split ratio. The carrier gas was He at a flow rate $0.9 \mathrm{~mL} / \mathrm{min}$, while the column temperature was linearly programmed in the range of $150-240{ }^{\circ} \mathrm{C}$ at a rate of $4{ }^{\circ} \mathrm{C} / \mathrm{min}$ and held at $240{ }^{\circ} \mathrm{C}$ for $10 \mathrm{~min}$. The transfer line was heated at 240 ${ }^{\circ} \mathrm{C}$. The FID detector temperature was $300{ }^{\circ} \mathrm{C}$. The $\mathrm{El}$ mass spectra (70 eV) were acquired in the $\mathrm{m} / \mathrm{z}$ range 40-500.

\section{RESULTS AND DISCUSSION}

Eight fatty acids were identified in $A$. undulatum: linoleic acid, $26.80 \%$, palmitic acid, $22.17 \%$, $\alpha$-linolenic acid, $20.50 \%$, oleic acid, $18.49 \%$, arachidonic acid, $6.21 \%$, stearic acid, 3.34\%, cis-5,8,11,14,17-eicosapentaenoic acid, $1.52 \%$ and behenic acid, $1.01 \%$, while six fatty acids were found in $\mathrm{H}$. andoi: palmitic acid, $63.48 \%$, erucic acid, $12.38 \%$, stearic acid, $8.08 \%$, behenic acid, $6.26 \%$, lignoceric acid, $5.16 \%$ and arachidic acid, $4.64 \%$.

The obtained results for $A$. undulatum are in good agreement with previous studies [9], since arachidonic acid and cis-5,8,11,14,17-eicosapentaenoic acid in monogalactosyldiacylglycerol (MGDG) fraction have been presented in small-scale as well ( 8 and $1 \%$, respectively). This moss species collected in winter time can be considered as a good source for in vitro production of both essential fatty acids for humans, linoleic acid and $\alpha$-linolenic acid [17]. A possible and the most appropriate way for the production of large amounts of $A$. undulatum that can be used for the isolation of highlighted fatty acids are corresponding in vitro culture. Therefore, the axenical culture of $A$. undulatum has been established. Further studies are needed to compare the content of fatty acids of in vitro grown and the plants from natural habitats.

\section{Acknowledgments}

This work was supported by the Ministry of Education and Science of the Republic of Serbia (Research grants Nos. 142053, 143015 and 173040).

\section{REFERENCES}

[1] H. Grum, Structural Diversity of Bryophytes, Ann Harbor, MI, 2001.

[2] Y. Asakawa, Recent advances in phytochemistry of bryophytes - acetogenins, terpenoids and bis(bibenzyl)s from selected Japanese, Taiwanese, New Zealand, Ar- gentian and European liverworts, Phytochemistry 56 (2001) 297-312.

[3] F. Nagashima, H. Tanaka, S. Takaoka, Y. Asakawa, Sesqui- and diterpenoids from the Japanese liverwort Jungermannia hattoriana, Phytochemistry 45 (1997) 353$-363$.

[4] F. Nagashima, H. Tanaka, S. Takaoka, Y. Asakawa, Eudesmane-type sesquiterpene lactons from the liverwort Frullania densiloba, Phytochemistry 45 (1997) 555-558.

[5] M. Toyota, H. Koyama, Y. Asakawa, Volatile components of the liverworts Archilejenea olivacea, Cheilolejeunea imbricata and Leptolejeunea elliptica, Phytochemistry 44 (1997) 1261-1264.

[6] T. Hashimoto, H. Irita, S. Takaoka, M. Tanaka, Y. Asakawa, New chlorinated cyclic bis(bibenzyls) from the liverworts Herbertus sakurai and Mastigophora diclados, Tetrahedron 56 (2000) 3153-3159.

[7] V. Herout, in: Diterpenes and Higher Terpenes from Bryophytes, Bryophytes, their Chemistry and Chemical Taxonomy, H.D. Zinsmeister, R. Mues (Eds.), Clarendon Press, Oxford, 1990, pp. 83-102.

[8] S. Huneck, in: Chemistry and Biochemistry of Bryophytes, New Manual of Bryology Vol. 1, R.M. Shuster (Ed.), The Hatory Botanical Laboratory, Nichian, Miyazaki, 1983, pp. 1-116.

[9] P. Karunen, in: The acyl lipids of Bryophytes, Bryophytes, their Chemistry and Chemical Taxonomy, H.D. Zinsmeister, R. Mues (Eds.), Clarendon Press, Oxford, 1990, pp. 121-141.

[10] V.M. Dembitsky, Lipids of bryophytes, Prog. Lipid Res. 32 (1993) 281-356.

[11] B. Pejin, Lj. Vujisić, M. Sabovljević, A. Sabovljević, V. Tešević, V. Vajs, Preliminary analysis of fatty acid chemistry of Kindbergia praelonga and Kindbergia stokesii (Brachytheciaceae), J. Serb. Chem. Soc. 75 (2010) 1637$-1640$.

[12] B. Pejin, Lj. Vujisic, M. Sabovljevic, V. Tesevic, V. Vajs, The moss Mnium hornum, a promising source of arachidonic acid, Chem. Nat. Compd. 48 (2012) 120-121.

[13] B. Pejin, Lj. Vujisic, M. Sabovljevic, V. Tesevic, V. Vajs, An insight into fatty acid composition of Calliergonella cuspidata, Asian J. Chem. 23 (2011) 5161-5162.

[14] B. Pejin, Lj. Vujisic, M. Sabovljevic, V. Tesevic, V. Vajs, Fatty acids of some moss species from Germany, Asian J. Chem. 23 (2011) 5187-5188.

[15] B. Pejin, Lj. Vujisić, M. Sabovljević, V. Tešević, V. Vajs, An insight into fatty acid chemistry of Rhytididelphus squarrosus (Hedw.) Warnst., Botanica Serbica 35 (2011) 99$-102$.

[16] B. Pejin, C. Iodice, G. Tommonaro, Lj. Vujisic, M. Sabovljevic, S. Newmaster, A. Bianco, V. Tesevic, V. Vajs, S. De Rosa, Fatty acids of Rhodobryum ontariense (Bryaceae), Nat. Prod. Res. 26 (2012) 696-702.

[17] G.O. Burr, M.M. Burr, On the nature and role of the fatty acids essential in nutrition, J. Biol. Chem. 86 (1930) 587-621. 


\section{IZVOD}

\section{HEMIJA MASNIH KISELINA Atrichum undulatum I Hypnum andoi}

Boris Pejin ${ }^{1}$, Ljubodrag Vujisić ${ }^{1}$, Marko Sabovljević ${ }^{2}$, Vele Tešević ${ }^{1}$, Vlatka Vajs ${ }^{3}$

${ }^{1}$ Univerzitet u Beogradu, Hemijski fakultet, Katedra za organsku hemiju, Beograd, Srbija

${ }^{2}$ Univerzitet u Beogradu, Institut za botaniku i Botanička bašta, Biološki fakultet, Beograd, Srbija

${ }^{3}$ Univerzitet u Beogradu, Institut za hemiju, tehnologiju i metalurgiju, Centar za hemiju, Beograd, Srbija

(Kratko saopštenje)

Kao doprinos izučavanju njihovog hemijskog sastava, u ovom radu GC i GC-MS analizom ispitivane su masne kiseline mahovina Atrichum undulatum (Hedw.) P. Beauv. (Polytrichaceae) i Hypnum andoi A.J.E. Sm. (Hypnaceae) sakupljene za vreme zimskog doba. $U$ ekstraktu hloroform/metanol 1:1 vrste $A$. undulatum identifikovano je osam viših masnih kiselina (linolna kiselina, 26,80\%, palmitinska kiselina, 22,17\%, $\alpha$-linolenska kiselina, 20,50\%, oleinska kiselina, 18,49\%, arahidonska kiselina, 6,21\%, stearinska kiselina, 3,34\%, cis-5,8,11,14,17-eikosapentaenska kiselina, $1,52 \%$ i behenska kiselina, $1,01 \%)$, dok je $u$ istom ekstraktu vrste $H$. andoi nađeno šest viših masnih kiselina (palmitinska kiselina, 63,48\%, erukinska kiselina, $12,38 \%$, stearinska kiselina, $8,08 \%$, behenska kiselina, 6,26\%, lignocerinska kiselina, 5,16\% i arahidinska kiselina, 4,64\%). Dobijeni rezultati ukazuju da u ispitivanom vremenskom periodu mahovina $A$. undulatum predstavlja dobar izvor linolne i $\alpha$-linolenske kiseline, esencijalnih masnih kiselina za ljude.
Ključne reči: Briofite • Mahovine • Fitohemija • GC FID • GC-MS • Linolna kiselina $\bullet \alpha$-Linolenska kiselina 